\title{
An Inconvenient Truth: Why Social Policies Might Fail
}

\author{
Dimas Suryo Sudarso ${ }^{1}$ \\ Ministry of National Development Planning/Bappenas - Indonesia
}

\begin{abstract}
Developing countries implemented social policies after suffered by economic and financial crisis. Social policies, such as conditional cash transfer, noncontributory social insurance policy, and energy subsidy, were introduced to improve the well-being of the society. However, these policies potentially fail and prevent these countries to converge to be developed countries, due to low level of human capital formation, increased informal employment, unsustainable fiscal capabilities, the induction of "pork-barrel politics" in the policy planning and formulation process, and reduced incentive to work. This essay also provided recommendation on social policies improvement. Thus, policymakers able to increase the effectiveness of current social policies to maintain the country's objective in reducing income inequality, without hampered the country's productivity and economic growth.
\end{abstract}

Keywords: social policy, human capital, fiscal.

${ }^{1}$ Dimas Suryo Sudarso is a Planner Staff at Directorate of Higher Education, Science and Technology, and Culture, Ministry of National Development Planning/Bappenas Republic of Indonesia. E-Mail: dimas.suryo@bappenas.go.id 
Pungky Widiaryanto

\title{
An Inconvenient Truth: Why Social Policies Might Fail
}

\author{
Dimas Suryo
}

The Great Depression in 1930s, Asian Financial Crisis in the end of 1990s, latin America Crises, and the Global Financial Crisis in 2007 are some of economic and financial crises that engulfed country or regions with high impact severity. As the crises passed, countries directed their fiscal policies to programs that support economic growth, reduce inequality and prevent the recurrence of the crisis. For example, the U.S. introduced social security program post The Great Depression, South Korea established Employment Insurance Program and revised their Minimum Living Standard Laws after the 1997 Asian Financial Crisis, and Mexico improved their pro-poor program through Progresa post Mexican Peso Crisis (Atkinson \& Morelli 2011; Kim 2015; Menocal 2005). Those examples of social policy aim to improve the well-being of society, especially people who in disadvantage. Various studies have appreciated the success of those social policies, including increasing school attainment for boys and girls, protection against financial risk, improving the quality of public health and reducing poverty (Azevedo \& Robles 2010; Miller, Pinto \& Vera-Hernandez 2013). Based on these achievements, optimism emerged that these developing countries would be able to catch up with developed countries. However, others claim that these social policies may not help developing countries in the long term and those countries will be potentially suffered by "middle income trap", a condition where a country stagnate at middle income levels and unable to transition into high-income economy. Thus, despite of amazing results and supported by numerous researches, stakeholders may wary about the implementation of social policies since the contradicted results may occurs. This essay will discuss why these social policies potentially fail and prevent these countries to converge to be developed countries, including the low level of human capital formation, increased informal employment, unsustainable fiscal capabilities, the induction of "pork-barrel politics" in the policy planning and formulation process, and reduced incentive to work.

Firstly, the social policy may produce low level of human capital. By providing social policies, countries able to increase public access to education and health services. For example, Indonesia has heavily invested in education by allocating twenty per cent of national budget into education sector. Indonesia introduced social policies in education, such as Bantuan Operasional Sekolah (school operational assistance fund program), Bantuan Siswa Miskin (cash transfer for poor students), and special allocation fund for providing schools' infrastructure. According to Indonesia Statistical Bureau (BPS) data (BPS 2018a, 2018b), Indonesia succeeded in increasing their school participation rate for the last decade, especially for group of children age 13-15 years old and 16-18 years old, as shown in Figure 1. School participation rate describes number of children in certain aged group who are currently in school, regardless of education level. 


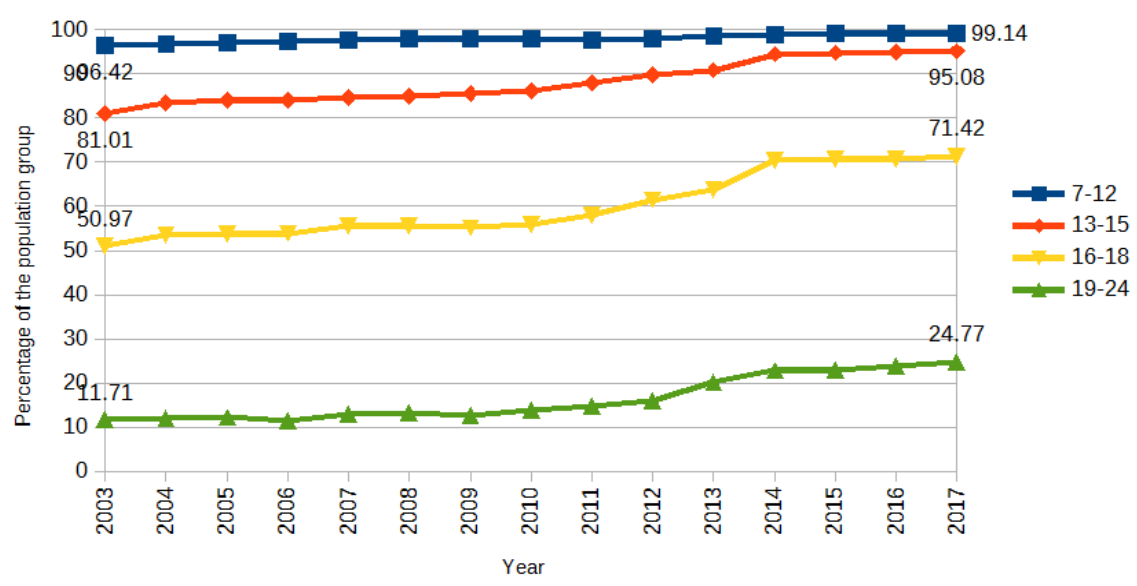

Figure 1. School Participation Rate in Indonesia Based on Age Group

(BPS 2018a, 2018b)

However, increasing number of children enrolled in school do not equal to increase in the quality of human capital. It is important to ensure that the policy in providing access to education is followed by the effort to increase the service's quality of education. Levy and Schady (2013) argue that low learning outcomes are caused by unequal in schools' quality and the low quality of teachers. Consequently, low learning outcome will contribute to low cognitive abilities in students and youth workforce. Using the Programme for International Student Assessment (PISA) data, as a proxy for student learning outcomes and quality of education, it was found that Indonesia is consistently in the lowest group of countries compared to others (Chang et al. 2013).

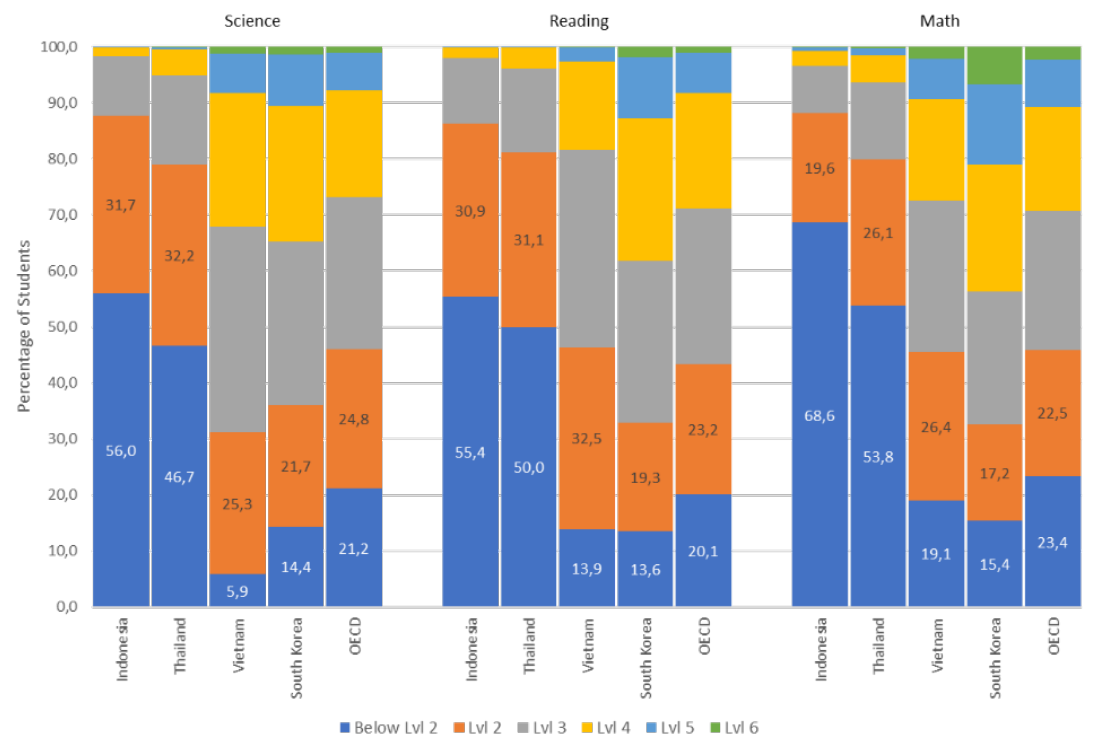

Figure 2. Percentage of Students at each Proficiency Level Across Countries by Subject (OECD 2016) 
Figure 2 shows that Indonesia has bigger percentage of low-achieving students, which are students with proficiency level 2 or below, compare to neighbouring countries and OECD. Thus, the Government of Indonesia's policy in increasing the school attainment has not significantly contributed to the improvement in cognitive abilities of Indonesia's students.

Similarly, increasing access in health services has indeed succeeded in increasing health outcomes and health services utilisation. However, there are still challenges in ensuring adequate nutrition for pregnant women and children. Children's cognitive abilities are also determined by this nutritional aspect (Levy \& Schady 2013). Low nutritional intake for children and pregnant women leads to low level human capital formation. Thus, it is insufficient to only increase access to the education and health service. The ultimate objective of social policies must be able to contribute to economic growth through the creation of high-level human capital.

Most of social policy that contribute to the increasing of education and health service utilisation was implemented by conditional cash transfer scheme (CCT). CCT is a policy that requires beneficiaries to carry out various requirements, such as sending children to school, regularly checking up with a doctor, so that the beneficiaries can receive the benefit in cash. Ganimian and Murnane (cited in Bauchet et al. 2018) state the impact of CCT program on academic and cognitive skills remained unclear. Thus, even though the level of education is increased, the study found mixed result on the outcome of education process that is measured by increase in cognitive skills. In contrary, Bauchet et al. (2018) find that the return to schooling for some populations, in their study refers to indigenous groups in Latin America, is lower during the implementation of CCT program. Similarly, Lomeli (2008) argue the CCT program has no positive effect on school learning. Low cognitive abilities are associated with increasing income inequality, which can then have an impact on low productivity and economic growth (Raudenbush \& Kasim 1998; Barro 2000). Therefore, the shortcomings in the existing social policies cause the effect of those policies to produce high-quality human capital and support intergenerational mobility may be limited.

Besides the low level of human capital, social policies are failing when the policies lead to the increasing of informal employment. Let using non-contributory social insurance policies as the example. This policy allows beneficiaries to receive social insurance without paying. Gertler and Bando (2016) find evidence that noncontributory social insurance has no impact on overall labour-force participation. However, it does increase the proportion of individuals in unpaid work and a decrease in paid work. With the presence of non-contributory social insurance, employers are motivated to employ more informal workers rather than formal workers, since there is no additional income to be set aside for paying contributory social insurance. Thus, the initial goals of the policy, which are to reduce informal worker in the labour market and to prevent workers to become an informal worker, cannot be achieved. In addition, non-contributory social insurance generates unfair losses for formal workers because they are considered "subsidising" informal workers (Lustig \& Pessino 2014). Similarly, Levy and Schady (2013) explain that providing non-contributory social insurance in Latin America regions discourages formal employment because informal workers can accept the benefits without having to pay through income tax. As the result of more informal workers employed in the economy, it will decrease total factor productivity as shown in Figure 3. The reason is the level of productivity of workers who work in the informal sector is lower than the formal workers (Busso et al. cited in Levy \& Schady 2013). Therefore, 
providing non-contributory social insurance policies will encourage informal employment and decrease total factor productivity.

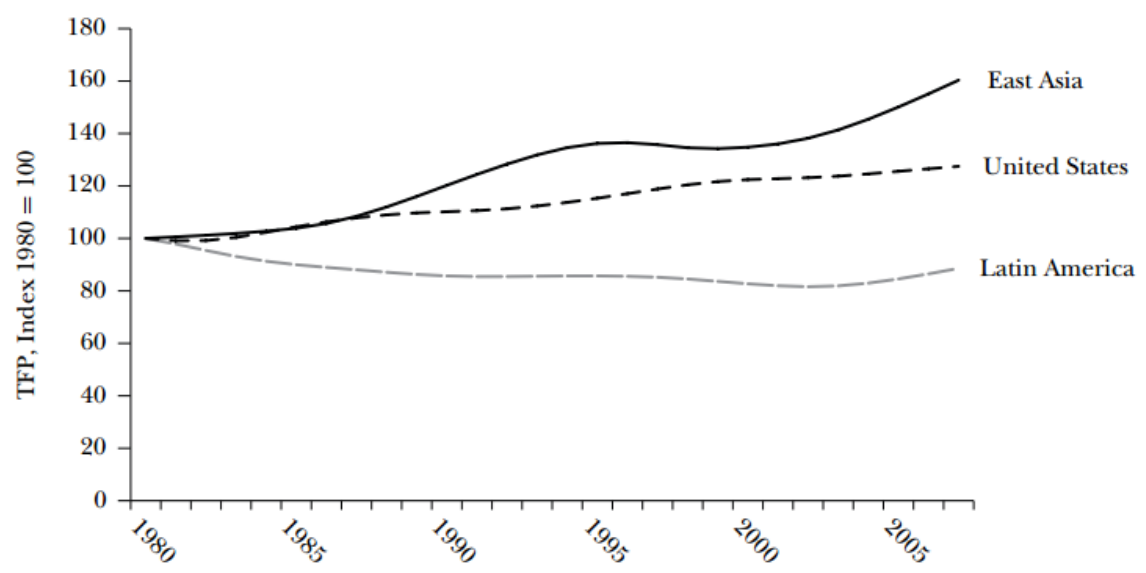

Figure 3. Total Factor Productivity (TFP) in Latin America, The U.S. and East Asia (Levy \& Schady 2013)

The third factor why social policies are failing is because the social policy is supported by unsustainable fiscal capabilities. Using Latin America region as case study, Levy and Schady (2013) criticise the magnitude of the scope and unit cost of social spending. For example, the provision of non-contributory pensions can burden the country's budget since the percentage of the population aged over 65 years compared to the workforce is increasing, as shown in Figure 4.

\begin{tabular}{|c|c|c|c|c|c|c|c|c|c|c|c|}
\hline \multirow[b]{3}{*}{ Country } & \multicolumn{6}{|c|}{ Noncontributory pensions (NCP) } & \multicolumn{5}{|c|}{ Conditional cash transfer programs (CCT) } \\
\hline & \multirow[b]{2}{*}{$N C P$} & \multirow[b]{2}{*}{ Age } & \multicolumn{2}{|c|}{ Coverage } & \multicolumn{2}{|c|}{ Transfers } & \multirow[b]{2}{*}{$C C T$} & \multicolumn{2}{|c|}{ Coverage } & \multicolumn{2}{|c|}{ Transfers } \\
\hline & & & $\begin{array}{c}\text { People } \\
\text { (thousand) }\end{array}$ & $\begin{array}{c}\% \text { of } \\
\text { elderly }\end{array}$ & $\begin{array}{c}\$ U S \\
\text { (monthly) }\end{array}$ & $\begin{array}{c}\% \\
G D P\end{array}$ & & $\begin{array}{l}\text { Households } \\
\text { (thousand) }\end{array}$ & $\begin{array}{c}\text { \% of } \\
\text { households }\end{array}$ & $\begin{array}{c}\$ U S * * * \\
(\text { monthly) }\end{array}$ & $\begin{array}{c}\% \\
G D P\end{array}$ \\
\hline Argentina & $\sqrt{ }$ & $70+$ & 41 & 1.4 & 248 & 0.03 & $\sqrt{ }$ & 1,876 & 21.1 & 162 & 0.49 \\
\hline Bolivia & $\sqrt{ }$ & $60+$ & 899 & 100 & 28 & 1.25 & $\sqrt{ }$ & 972 & 40.2 & 5 & 0.23 \\
\hline Brazil & $\sqrt{*}$ & $60+$ & 7,340 & 32.5 & 328 & 1.16 & $\sqrt{ }$ & 13,352 & 28.2 & 45 & 0.41 \\
\hline Chile & $\sqrt{ }$ & $65+$ & 842 & 53.5 & 136 & 0.55 & $\sqrt{ }$ & 264 & 5.9 & 104 & 0.13 \\
\hline Colombia & $\sqrt{ }$ & $57+$ & 768 & 15.6 & 33 & 0.09 & $\sqrt{ }$ & 2,438 & 23 & 33 & 0.22 \\
\hline Costa Rica & $\sqrt{ }$ & $65+$ & 93 & 30.6 & 146 & 0.4 & $\sqrt{ }$ & 143 & 12.7 & 74 & 0.23 \\
\hline $\begin{array}{c}\text { Dominican } \\
\text { Republic }\end{array}$ & & & & & & & $\sqrt{ }$ & 831 & 34.7 & 25 & 0.24 \\
\hline Ecuador & $\sqrt{ }$ & $65+$ & 536 & 58.2 & 35 & 0.34 & $\sqrt{ }$ & 1,212 & 34 & 35 & 0.71 \\
\hline El Salvador & $\sqrt{ }$ & $60+$ & 20 & 3.4 & 50 & 0.05 & $\sqrt{ }$ & 95 & 7.1 & 17 & 0.15 \\
\hline Guatemala & & & & & & & $\sqrt{ }$ & 873 & 37.4 & 29 & 0.24 \\
\hline Honduras & & & & & & & $\sqrt{ }$ & 412 & 27.7 & 40 & 0.32 \\
\hline Mexico & $\sqrt{* *}$ & $70+$ & 2,149 & 44.9 & 40 & 0.09 & $\sqrt{ }$ & 5,827 & 24.2 & 72 & 0.46 \\
\hline Panama & $\sqrt{ }$ & $70+$ & 85 & 56.5 & 100 & 0.34 & $\sqrt{ }$ & 74 & 10 & 50 & 0.15 \\
\hline Paraguay & $\sqrt{ }$ & $65+$ & 25 & 7.4 & 92 & 0.11 & $\sqrt{ }$ & 94 & 7.1 & 38 & 0.13 \\
\hline Peru & $\sqrt{ }$ & $65+$ & 26 & 1.5 & 46 & 0.01 & $\sqrt{ }$ & 474 & 7.1 & 36 & 0.13 \\
\hline Uruguay & $\sqrt{ }$ & $65+$ & 33 & 7.1 & 238 & 0.2 & $\sqrt{ }$ & 207 & 24.7 & 83 & 0.48 \\
\hline $\begin{array}{l}\text { Latin } \\
\text { America }\end{array}$ & & & 12,858 & 33.4 & 178 & 0.56 & & 29,143 & 22.6 & 64 & 0.37 \\
\hline
\end{tabular}

Figure 4. Noncontributory Pensions and Conditional Cash Transfer Programs in Latin America, 2011 (Levy \&Schady 2013) 
Figure 5 also describes the rising in unit cost of social assistance. In addition to cash transfers and non-contributory social insurance, social policies that generally have a larger portion on a national budget are subsidies. For example, energy or fuel subsidies. Since these types of subsidies are imposed to the products, not targeted to specific beneficiaries, and can be consumed by everyone, this policy is prone to misallocation and mistargeted. For example, $57 \%$ of the electricity subsidy budget is consumed by the two-top economic quintile in Mexico (Levy \& Schady 2013). Without a proper calculation and improvement, social policies' expenditures will burden the fiscal conditions of a country in the future.

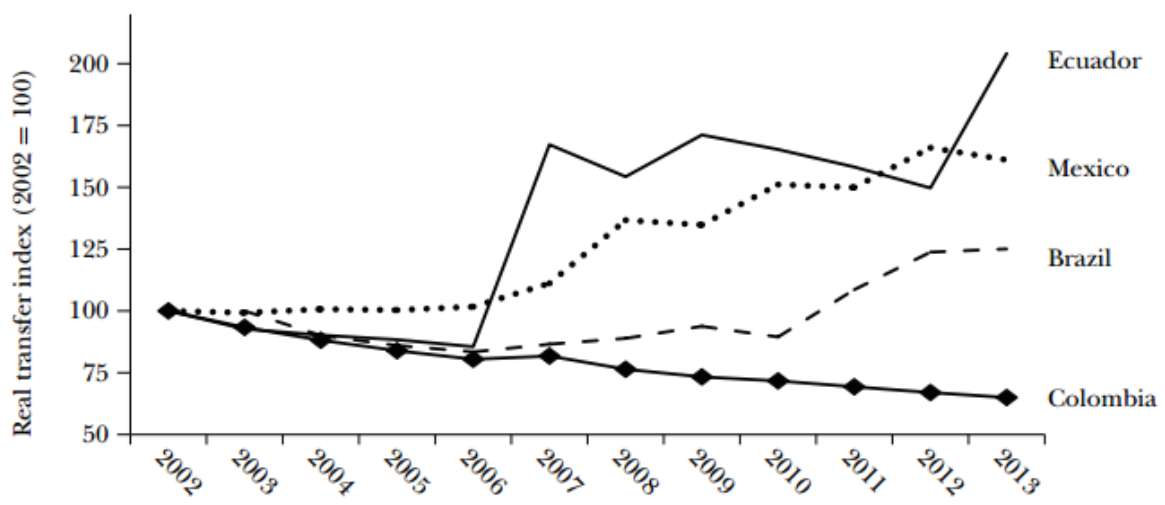

Figure 5. The Evolution of Transfers in Cash Transfer Programs in Latin America (Levy \& Schady 2013)

Fourthly, the social policies are failing when the policies were induced by the "pork-barrel politics". Dixit and Londregan (1998) argue that the redistribution policy could be considered as an effort to gain the sympathy of voters. Similarly, Bucheli (2015) criticise the social policies, especially CCTs and anti-poverty programmes, that commonly used as incumbents' strategy to mobilise and diversify their political supports in order to retain political power for future elections. Thus, this social policy potentially changes its meaning from long-term efforts to improve people's welfare to be a short-term effort to achieve political goals and may endanger the sustainability of the country's fiscal budget. However, the tendency of porkbarrel politics does not necessarily a bad thing. Putting different perspective, political rewards can only gain through the implementation of successful social policy. Without better and successful social policy, voters will allocate their preferences to other more promising social policy offers (Finan \& Schechter cited in Bucheli 2015). Thus, as a political process, the current social policies may lead to the cycle of better policy formulation in the future.

Lastly, the social policies are failing because it led to the reduction in incentive to work. Social policies that are redistributive resources, such as CCT program, able to support the household from low economic quintile. However, Levy and Schady (2013) debate that if the value of social policy's assistance is too large, it can discourage beneficiaries to work. The reason is the beneficiary is rewarded for being poor, so they want to remain poor to gain the assistance. If leisure is assumed as normal good, increasing cash transfer will result in income effects and potentially reduce labour supply. Nevertheless, this argument has not received support from various studies. Hoynes and Schanzenbach (2012) found that income transfer policies did not significantly affect employment. In their study, only one group of 
the entire sample, which is a single parent household with a female head, experience disincentive effects due to the income transfers. Skoufias and Maro (2008) also found that income transfers do not provide a significant effect on adult labour supply, unlike those that occur in the U.S. and Canada's welfare programs. Therefore, this last argument should be interpreted cautiously since more data and study are needed to explain the argument that social policy disincentive people to work.

Based on the discussion, the government in developing countries should improve their social policies to be more effective. Firstly, increase tax collection, especially personal income taxes from higher income households. Noting that increasing tax collection may backfire and create greater tax loss if it imposes taxes on a minority of highly skilled workers. Policymakers should pay attention to the trade-off between equity and efficiency. Secondly, redistribute social policies that are ineffective and untargeted, such as the energy subsidies, to human capital improvement programs that support productivity. For example, expanding job training program, improving teacher quality and investing in early childhood development programs. Thirdly, improve and simplify regulations. Sojo (2016) emphasises this to facilitate the formalisation of employment. For example, simplification of tax and retirement scheme, adjustment of employers' contribution depending on company size, and a tax break for firms that formalised their activities. This policy is intended to prevent recipients of social assistance who choose to work as informal workers and for employers who choose to employ informal workers. Fourthly, improve country's institution. Fatica (2010) argues that tax collection can be increased by improving institution through bureaucracy and taxes reforms. Therefore, the government can gain the society's trust, reduce tax avoidance and reduce 'the grabbing hand' or corruption in the government. By implementing these improvements, the policymakers are able to maintain their objective in income inequality reduction, without reducing the country's productivity and economic growth.

In conclusion, existing social policies have potential to fail and prevent developing countries to converge to be developed countries if improvements do not administer properly. Increased access to education and health service must be followed by the increase in services' quality to achieve better human capital formation. Social policies should not have negative implications for labour supply, such as a disincentive for people to work or move to informal employment. Policymakers should reduce over-reliance on existing social policy programs for future fiscal sustainability. Improvement of existing social policies will be done continuously as a part of political process. Policy implications and proposed policy improvements focused on the growth of the country's productivity and financial sustainability, without allowing wider inequality through better redistributive policies. Noting that, the discussion and proposed policy cannot be applied and generalised to all countries due to complexity and countries' differences, such as differences in income, country's size, institution, and endowment level.

\section{Reference}

Atkinson, AB \& Morelli, S 2011, 'Economic crises and inequality', Journal of Development Effectiveness Human Development Research Paper, no. 2011/6, pp. 1-70.

Azevedo, VMR \& Robles, M 2010, 'Simulating the impact of policy changes in Mexico's PROGRESA/Oportunidades', Journal of Development

Effectiveness, vol. 2, no. 2, pp. 263-286. 
Badan Pusat Statistik (BPS) 2018a, Angka Partisipasi Sekolah (APS) menurut Provinsi 2003-2010 [School Participation Rate by Province 2003-2010], dataset, BPS, viewed 24 October 2018, $<$ https://www.bps.go.id/dynamictable/2015/12/22/1053/angkapartisipasi-sekolah-aps-menurut-provinsi-2003-2010.html>.

Badan Pusat Statistik (BPS) 2018b, Angka Partisipasi Sekolah (APS) menurut Provinsi 2011-2017 [School Participation Rate by Province 2011-2017], dataset, BPS, viewed 24 October 2018, $<$ https://www.bps.go.id/dynamictable/2015/12/22/1054/angkapartisipasi-sekolah-aps-menurut-provinsi-2011-2017.html >.

Barro, RJ 2000, 'Inequality and growth in a panel of countries', Journal of Economic Growth, vol. 5, pp. 5-32.

Bauchet, J, Undurraga, EA, Reyes-Garcia, V, Behrman, JR \& Godoy, RA 2018, 'Conditional cash transfers for primary education: Which children are left out?', World Development, vol. 105, pp. 1-12.

Bucheli, JF 2015, 'Conditional cash transfer schemes and the politicisation of poverty reduction strategies', Analisis Politico, vol. 28, no. 83, pp. 19-31.

Chang, MC, Shaeffer, S, Al-Samarrai, S, Andrew, BR, Ree, JD \& Stevenson, R 2013, Teacher reform in Indonesia: The role of politics and evidence in policy making, Directions in Development - Human Development: The World Bank.

Dixit, A \& Londregan, J 1998, 'Ideology, tactics, and efficiency in redistributive politics', The Quarterly Journal of Economics, vol. 113, no. 2, pp. 497-529.

Fatica, S 2010, Taxation and the quality of institutions: asymmetric effects on FDI, Office for Official Publications of the European Communities, Luxembourg.

Galiani, S, Gertler, P \& Bando, R 2016, 'Non-contributory pensions', Labour Economics, vol. 38, pp. 47-58.

Hoynes, HW \& Schanzenbach, DW 2012, 'Work incentives and the Food Stamp Program', Journal of Public Economics, vol. 96, pp. 151-162.

Kim, S 2005, 'Economic crisis, domestic politics and welfare state changes', The Pacific Review, vol. 18, no. 3, pp. 375-391.

Levy, S \& Schady, N 2013, 'Latin America's social policy challenge: education, social insurance, redistribution', Journal of Economic Perspectives, vol. 27, no. 2, pp. 193-218.

Lomeli, EV 2008, 'Conditional cash transfers as social policy in Latin America: an assessment of their contributions and limitations', Annual Review of Sociology, vol. 34, pp. 475-498.

Lustig, N \& Pessino, C 2014, 'Social spending and income redistribution in Argentina during the 2000s: The increasing role of noncontributory pensions', Public Finance Review, vol. 42, no. 3, pp. 304-325.

Menocal, AR 2005, 'Less political and more pro-poor? The evolution of social welfare spending in Mexico in a context of democratisation and decentralisation', Nord-Sud Aktuell, vol. 3, no. 4, pp. 346-359.

Miller, G, Pinto, D \& Vera-Hernandez, M 2013, 'Risk protection, service use, and health outcomes under Colombia's health insurance program for the 


\section{Dimas Suryo}

poor', American Economic Journal: Applied Economics, vol. 5, no. 4, pp. 6191.

OECD 2016, PISA 2015 Results (Volume I): Excellence and Equity in Education, OECD Publishing, Paris, <http://dx.doi.org/10.1787/9789264266490en>

Raudenbush, SW \& Kasim, RM 1998, 'Cognitive skill and economic inequality: Findings from the National Adult Literacy Survey', Harvard Educational Review, vol. 68, no. 1, pp. 33-79.

Skoufias, E \& Maro, VD 2008, 'Conditional cash transfers, adult work incentives, and poverty', The Journal of Development Studies, vol. 44, no. 7, pp. 935960.

Sojo, A 2016, 'Including informal economy workers in contributory social protection: Current challenges in Latin America', International Social Security Review, vol. 68, pp. 69-92. 